\title{
PENGARUH PENERAPAN STRATEGI PEMBELAJARAN KOOPERATIF STUDENT TEAM ACHIEVEMENT DIVISION DAN AKTIVITAS BELAJAR TERHADAP HASIL BELAJAR AL-QUR'AN HADITS SISWA MADRASAH TSANAWIYAH NEGERI 3 SIMALUNGUN
}

\author{
Nurhayati \\ Guru MTsN 3 Simalungun
}

\begin{abstract}
The purpose of this study was to find out: (1) the effect of the application of STAD cooperative learning strategies to the learning outcomes of AlQur'an Hadiths of Simalungun MTs Negeri 3 students, (2) the effect of learning activities on learning outcomes of Al-Qur'an Hadith students of MTs Negeri 3 Simalungun, (3) the interaction of the application of STAD cooperative learning strategies and learning activities to the learning outcomes of Al-Qur'an Hadith students of Simalungun MTs Negeri 3. This type of research is quantitative research with research methods used are experiments. The population of this study were all class VIII which consisted of 5 classes. The sampling technique is used cluster random sampling. This technique was chosen because what was sampled from the population was the number of classes (as many as 5 classes) rather than the number of students in the population. STAD cooperative learning strategy class is class VIII1 with 36 students and Class VIII3 as expository learning class with 38 students. The data collection technique is a learning outcome test and questionnaire. Data analysis technique is analysis of variance tested at $a=0.05$. Findings The results of the study were: (1) the average learning outcomes of students taught with STAD cooperative learning strategies $=28$ higher than the average student learning outcomes taught with expository learning strategies $=26.95$, with $\mathrm{F}_{\text {count }}=27.44>$ $\mathrm{F}_{\text {table }}=3.98,(2)$ the average student learning outcomes with high learning activities $=29.61$ higher than student learning outcomes with low learning activities $=26.07$ with $\mathrm{F}_{\text {count }}=6.17>\mathrm{F}_{\text {table }}=3.98$, and (3) there is an interaction between learning strategies and learning activities towards Civics learning outcomes with $\mathrm{F}_{\text {count }}=18.27>\mathrm{F}_{\text {table }}=3.98$.
\end{abstract}

\section{Keyword: Cooperative Student Team Achievement Division, Learning Activities and Learning Outcomes}

\section{PENDAHULUAN}

Pembelajaran di madrasah, terdapat banyak unsur yang saling berkaitan dan menentukan keberhasilan dalam proses pembelajaran. Unsur-unsur tersebut adalah: pendidik (guru), peserta didik (siswa), kurikulum, pengajaran, dan lingkungan. Siswa sebagai subjek dalam proses tersebut juga sangat berperan dalam keberhasilan kegiatan 
pembelajaran. Berkaitan dengan hal ini Sagala (2012) menjelaskan pembelajaran merupakan proses komunikasi dua arah, mengajar dilakukan oleh guru sebagai pendidik, sedangkan belajar dilakukan oleh siswa.

Salah satu tugas pendidik atau guru adalah menciptakan suasana pembelajaran yang dapat membuat siswa untuk senantiasa belajar dengan baik dan bersemangat. Suasana pembelajaran yang demikian akan berdampak positif dalam pencapaian prestasi belajar yang optimal. Guru sebaiknya memiliki kemampuan dalam memilih metode atau strategi pembelajaran yang tepat. Ketidaktepatan dalam penggunaan metode atau strategi pembelajaran akan menimbulkan kejenuhan bagi siswa dalam menerima materi yang disampaikan sehingga materi kurang dapat dipahami yang akan mengakibatkan siswa menjadi apatis. Oleh karena itu guru tidak hanya dituntut memiliki pengetahuan dan kemampuan mengajar, tetapi juga mewujudkan kompleksitas peran sesuai dengan tugas dan fungsi yang diembannya secara kreatif (Agung, 2010).

Mencermati penjelasan di atas maka dapatlah dipahami bahwa ketidaktepatan penyampaian materi ajar tentunya berakibat dari kurang maksimalnya pencapaian hasil belajar. Dalam hal ini hasil belajar dijelaskan Dimyati dan Mudjiono (2009) yaitu hasil dari suatu interaksi tindak belajar dan tindak mengajar Sementara itu Djamarah dan Zain (2002) menjelaskan bahwa hasil belajar adalah penguasaan peserta didik terhadap bahan/materi pelajaran yang telah guru berikan ketika proses mengajar berlangsung.

Mata pelajaran Al-Qur'an Hadits merupakan salah satu bagian dalam mencapai tujuan pendidikan untuk menjadikan manusia yang kamil (sempurna). Pendidikan sebagai transfer of knowledge merupakan hal yang utama dalam menyampaikan ajaran-ajaran yang tertuang dalam AlQur'an dan Al-Hadits sebagai sumber utama ajaran agama Islam. Di mana dengan adanya pendidikan ini maka ajaran-ajaran agama dapat diwariskan kepada generasi berikutnya dan benar-benar terinternalisasi dalam diri generasi mendatang.

Penerapan strategi yang tepat maka materi ajar dalam pembelajaran Al-Qur'an Hadits dapat diserap oleh anak didik dengan sebaik-baiknya. Strategi yang tepat akan menentukan efektifitas dan efisiensi pembelajaran. Sebagai seorang guru pendidik agama Islam maka perlu mengetahui strategi-strategi pembelajaran yang dapat diterapkan dalam pembelajaran. Dengan mengetahui strategi-strategi tersebut maka guru diharapkan mampu menyampaikan materi-materi ajaran agama Islam dengan berbagai variasi sehingga tujuan pembelajaran Islam dapat tercapai dengan lebih mudah.

Guru mempunyai peran yang sangat strategis dalam peningkatan mutu pendidikan di Indonesia. Mereka diharapkan dapat mengembangkan potensi yang dimiliki para siswa agar dapat menghayati dan mengamalkan ajaran agama Islam dalam kehidupan sehari-hari. 
Mereka adalah figur yang utama dalam menanamkan nilai-nilai ajaran agama Islam dalam kerangka pembentukan sikap dan watak, serta perilaku akhlakul karimah melalui berbagai strategi pembelajaran yang dikembangkan di madrasah.

Upaya untuk merealisasikan pelaksanaan pembelajaran Al-Qur'an Hadits, guru dituntut untuk menguasai pengetahuan yang memadai dan teknik-teknik mengajar yang baik agar ia mampu menciptakan suasana pengajaran yang efektif dan efisien atau dapat mencapai hasil yang sesuai dengan tujuan yang diharapkan. Sebagian besar teknik dan suasana pengajaran di madrasah-madrasah membuat siswa harus mau mendengarkan, mau menerima seluruh informasi dan mentaati segala perlakuan gurunya.

Disamping penerapan strategi pembelajaran, yang tak kalah pentingnya adalah memperhatikan karakteristik siswa dalam melakukan aktivitas belajar. Dalam hal ini aktivitas belajar siswa yang merupakan faktor yang harus diperhatikan guru agar pecapaian hasil belajar siswa dapat dicapai secara maksimal. Bagi seorang guru, melahirkan sikap positif merupakan suatu hal yang sangat penting dilakukan untuk semua mata pelajaran, termasuk mata pelajaran Al-Qur'an Hadits. Karena dengan sikap positif ini akan muncul kecintaan atau rasa suka terhadap mata pelajaran tertentu. Dan secara otomatis rasa suka atau kecintaan terhadap mata pelajaran tertentu akan menimbulkan kegairahan bagi siswa untuk mempelajarinya.

Hal ini berarti aktivitas belajar yang dilakukannya berhubungan dengan mata pelajaran yang ia senangi juga akan meningkat. Misalnya, siswa akan belajar meskipun tidak ada guru di dalam kelas, ia akan mengulang atau mempelajari materi yang sudah atau belum dipelajari meskipun tidak ada yang mengintruksikannya, membuat rangkuman, menggarisbawahi materi-materi yang dianggap penting, menyiapkan peralatan belajar yang akan digunakan keesokan harinya, dan lain sebagainya.

\section{KAJIAN TEORETIS}

Strategi pembelajaran dijelaskan Uno (2008) yaitu cara-cara yang akan dipilih dan digunakan oleh seorang pengajar untuk menyampaikan materi pebelajaran sehingga akan memudahkan peserta didik menerima dan memahami materi pembelajaran yang pada akhirnya tujuan pembelajaran dapat dikuasainya di akhir kegiatan belajar. Selanjutnya Haidir dan Salim (2012) yaitu pendekatan umum serta rangkaian tindakan yang akan diambil dan digunakan guru untuk memilih beberapa metode pembelajaran yang sesuai dalam pembelajaran.

Rusmono (2012) memaparkan strategi pembelajaran adalah pedoman umum yang berisi komponen-komponen yang berbeda dari pembelajaran agar mampu mencapai keluaran yang diinginkan secara optimal di bawah kondisi-kondisi yang diciptakan. Selanjutnya Isjoni 
(2007) menjelaskan strategi pembelajaran merupakan rancangan dasar bagi seorang guru tentang cara ia membawakan pengajarannya di kelas secara bertanggung jawab.

Salah satu model dalam pembelajaran kooperatif adalah Student Team Achievement Division (STAD). Slavin (2005) menjelaskan STAD merupakan salah satu model pembelajaran kooperatif yang paling sederhana dan merupakan model yang paling baik untuk permulaan bagi gutu yang baru menggunakan pendekatan kooperatif. Selanjutnya dijelaskan Slavin bahwa STAD terdiri dari atas lima komponen utama yaitu presentasi kelas, tim, kuis, skor kemajuan individual dan rekognisi tim.

Al-Tabany (2014) menjelaskan persiapan di dalam melaksanakan pembelajaran kooperatif yaitu: (1) perangkat pembelajaran. Sebelum melaksanakan pembelajaran perlu dipersiapkan perangka pembelajaran meliputi rencana pelaksanaan pembelajaran (RPP), buku siswa, dan lembar kegiatan siswa, (2) membentuk kelompok. Menentukan anggota kelompok diusahakan agar kemampuan siswa dalam kelompok heterogen, dan kemampua antar satu kelompok dengan kelompok lainnya relatif homogen, (3) menentukan skor awal. Skor awal yang dapat digunakan adalah nilai ulangan sebelumnya. Skor ini dapat berubah setelah ada kuis, (4) pengaturan tempat duduk. Pengaturan tempat duduk juga perlu dilakukan, hal ini dimaksudkan untuk menunjang keberhasilan pembelajaran. Apabila tidak ada pengaturan tempat duduk maka dapat menimbulkan kekacauan yang menyebabkan gagalnya pembelajaran, dan (5) kerja kelompok. Untuk mencegah adanya hambatan pada pembelajaran kooperatif model STAD maka terlebih dahulu diadakan latihan kerjasama kelompok. Hal ini bertujuan untuk lebih jauh mengenalkan masing-masing individu dalam kelompok.

Sagala (2012) menjelaskan strategi pembelajaran ekspositori bertolak dari pandangan, tingkah laku kelas dan penyebaran pengetahuan dikontrol dan ditentukan oleh guru/pengajar. Siswa dipandang sebagai objek yang menerima apa yang diberikan guru. Brady sebagaimana dikutip Rusmono (2012) menjelaskan strategi pembelajaran ekspositori adalah strategi yang terpusat kepada guru dengan fokus pendekatan melalui ceramah (naration), penjelasan serta penggunaan latihan dan perbaikan dalam mengkoordinir belajar siswa.

Sanjaya (2014) menjelaskan strategi pembelajaran ekspositori adalah strategi pembelajaran yang menekankan kepada proses penyampaian materi secara verbal dari seorang guru kepada sekelompok siswa dengan maksud agar siswa dapat menguasai materi pelajaran secara optimal. Gulo (2008) menjelaskan strategi pembelajaran ekspositori dilakukan guru mengolah secara tuntas pesan/materi sebelum disampaikan di kelas sehingga peserta didik tinggal menerima saja. Hal senada dijelaskan Rusmono (2012) bahwa strategi pembelajaran merupakan bentuk dari pendekatan pembelajaran yang berorientasi 
kepada guru, karena dalam strategi ini guru memegang peran yang sangat dominan. Melalui strategi ini guru menyampaikan materi pelajaran secara terstruktur dengan harapan materi pelajaran yang disampaikan dapat dikuasai siswa dengan baik.

Aktivitas belajar dijelaskan Slameto (2003) menegaskan merupakan kegiatan pembelajaran baik rohani yang menghendaki bekerjanya fungsi pemikiran maupun jasmani yang menghendaki gerakan fungsi otot-otot individu yang belajar. Dalam kegiatan belajar kedua aktivitas tersebut harus selalu berkaitan. Piaget sebagaimana dikutip Nasution (2005), menyatakan bahwa seorang anak berpikir sepanjang ia berbuat. Jadi tanpa melakukan sesuatu perbuatan siswa belum rasional cara berpikirnya, oleh sebab itu guru hendaknya dapat menciptakan kondisi yang baik sehingga memungkinkan setiap siswa dapat mengembangkan kreativitasnya.

Thorndike dan Woodworth sebagaimana dikutip Soetomo (2003) menjelaskan bahwa berlatih untuk tugas tertentu memudahkan belajar di waktu kemudian hanya untuk tugas yang serupa, bukan untuk tugas yang tidak serupa. Hubungan ini dikenal dengan istilah alih latihan dan transfer training. Akibat adanya pembiasaan-pembiasaan dalam belajar maka apa yang dipelajari tersebut lebih bermakna dalam ingatan dan pikiran. Prawiradilaga (2008) menjelaskan kebermaknaan (meaningfull) mempengaruhi ingatan, dalam arti bahwa semakian sesuatu keterangan atau informasi itu bermakna, maka semakin mudah pula keterangan tersebut dipahami

Hamalik (2003) menjelaskan manfaat aktivitas dalam belajar sebagai berikut: (1) siswa mencari berbagai pengalaman sendiri dan juga dapat secar langsung mengalami sendiri, (2) memupuk kerjasama yang harmonis di kalangan siswa sehingga memperlancar kerja kelompokkelompok belajar, (3) siswa belajar dan bekerja berdasarkan minat dan kemampuan yang dimilikinya sendiri, (4) berbuat secara individual sehingga dapat mengembangkan semua aspek pribadi yang dimiliki siswa itu sendiri, (5) memupuk disiplin belajar dan suasana belajar yang demokratis kekeluargaan, musyawarah dan mufakat, (6) membina dan memupuk kerjasama antar sekolah, masyarakat, guru dan orang tua siswa, (7) pembelajaran dan belajar dilaksanakan secara realistik dan holistik, dan (8) suasana pembelajaran yang dilaksanakan guru baik di dalam maupun luar kelas menjadi lebih hidup dan menyenangkan.

\section{METODOLOGI PENELITIAN}

Penelitian ini akan dilaksanakan di Madrasah Tsanawiyah Negeri 3 Simalungun. Metode yang dipergunakan dalam penelitian ini adalah metode quasi-eksperimen. Populasi dalam penelitian ini adalah seluruh siswa kelas VIII yang terdiri dari 5 kelas dengan jumlah 178. eknik penentuan sampel digunakan cluster random sampling. Teknik ini dipilih karena yang disampling dari populasi adalah jumlah kelas (sebanyak 5 kelas) bukan jumlah siswa dalam populasi. Sampel yang diambil terdiri 
dari dua kelompok yaitu satu kelompok kelas dilakukan pembelajaran menggunakan pembelajaran kooperatif STAD dan satu kelas lainnya dilakukan pembelajaran ekspositori. Instrumen pengumpulan data adalah angket dan tes. Teknik analisis data yang digunakan analisis varians dua jalur.

\section{HASIL PENELITIAN DAN PEMBAHASAN}

Rata-rata hasil belajar Al-Qur'an Hadits siswa Madrasah Tsanawiyah Negeri 3 Simalungun yang diajar dengan strategi pembelajaran kooperatif STAD $(\bar{X}=28)$ lebih tinggi daripada rata-rata hasil belajar Al-Qur'an Hadits siswa Madrasah Tsanawiyah Negeri 3 Simalungun yang diajar dengan strategi pembelajaran ekspositori $(\bar{X}=$ 26,95). Hal ini menunjukkan bahwa strategi pembelajaran kooperatif STAD terbukti efektif dapat meningkatkan hasil belajar Al-Qur'an Hadits siswa Madrasah Tsanawiyah Negeri 3 Simalungun secara keseluruhan baik untuk kelompok siswa dengan aktivitas belajar tinggi maupun kelompok siswa dengan aktivitas belajar rendah. Dengan demikian dapatlah dimaknai bahwa strategi pembelajaran kooperatif STAD lebih efektif untuk meningkatkan hasil belajar Al-Qur'an Hadits siswa Madrasah Tsanawiyah Negeri 3 Simalungun tanpa memperhatikan aktivitas belajar siswa.

Pelaksanaan pembelajaran Kooperatif STAD dilaukan siswa dikelompokkan dalam satu kelompok yang terdiri dari 4-5 orang siswa/kelompok yang merupakan campuran menurut tingkat kinerja, jenis kelamin dan suku. Guru menyajikan pelajaran kemudian siswa bekerja dalam tim untuk memastikan bahwa seluruh anggota tim telah menguasai pelajaran tersebut. Akhirnya, seluruh siswa dikenai kuis tentang materi itu di mana pada saat kuis mereka tidak boleh saling membantu yang pada akhirnya mereka harus mampu untuk bekerja menyelesaikan tugasnya secara individual. Pada pembelajaran kooperatif diajarkan keterampilan- keterampilan khusus agar dapat bekerja sama dengan baik di dalam kelompoknya, seperti menjadi pendengar yang baik, siswa diberi lembar kegiatan yang berisi pertanyaan atau tugas yang direncanakan untuk diajarkan. Selama kerja kelompok, tugas anggota kelompok adalah mencapai ketuntasan

Hal ini dapat terjadi karena dalam pembelajaran yang menerapkan strategi pembelajaran kooperatif STAD siswa cenderung aktif untuk merekonstruksi sendiri ilmu yang akan diperolehnya, siswa berupaya menemukan dan menyelesaikan masalah dalam kerangka pencapaian tujuan pembelajaran. Pembelajaran kooperatif STAD adalah strategi pembelajaran yang berorientasi pada aktivitas siswa dalam mengkonstruksi pengetahuannya melalui aktivitas belajar yang dilakukan siswa sebagaimana dijelaskan Wena (2009) bahwa siswa mengeksplorasi konsep dari pengalaman dan situasi kehidupan sehari-hari dan kemudian 
menguji pendapatnya.

Pengujian hipotesis pertama menunjukkan hasil yang signifikan yaitu hasil belajar Al-Qur'an Hadits siswa Madrasah Tsanawiyah Negeri 3 Simalungun antara siswa yang diajar dengan strategi pembelajaran kooperatif STAD lebih tinggi daripada hasil belajar Al-Qur'an Hadits siswa yang diajar dengan strategi pembelajaran ekspositori. Hal ini dapat dimaklumi karena melalui strategi pembelajaran kooperatif STAD dapat mendorong siswa untuk aktif belajar karena siswa dapat menghubungkan yang mereka pelajari dengan materi sebelumnya dan struktur kognitif yang sudah dimiliki siswa. Di samping itu strategi pembelajaran kooperatif STAD bertujuan menumbuhkan partisipasi siswa dalam memecahkan isu atau masalah yang diajukan oleh guru dalam pembelajaran, menumbuhkan diskusi di antara siswa dalam mencari penyebab dan solusi terhadap isu atau masalah tersebut. Oleh karena itu peran guru dalam strategi pembelajaran kooperatif STAD lebih dominan sebagai fasilitator yang mengarahkan siswa untuk menemukan dan mengkonstruk sendiri pengetahuannya.

Rata-rata hasil belajar Al-Qur'an Hadits siswa Madrasah Tsanawiyah Negeri 3 Simalungun dengan aktivitas belajar tinggi $(\bar{X}=$ 29,61 ) secara keseluruhan baik yang diajar dengan strategi pembelajaran kooperatif STAD dan strategi pembelajaran ekspositori lebih tinggi baik daripada rata-rata hasil belajar Al-Qur'an Hadits siswa Madrasah Tsanawiyah Negeri 3 Simalungun dengan aktivitas belajar rendah $(\bar{X}=$ $26,07)$. Hal ini menunjukkan bahwa aktivitas belajar tanpa memperhatikan strategi pembelajaran yang diterapkan berpengaruh terhadap hasil belajar Al-Qur'an Hadits siswa Madrasah Tsanawiyah Negeri 3 Simalungun. Untuk itu peran guru dalam kegiatan pembelajaran adalah memperhatikan aktivitas belajar siswa sehingga strategi yang diterapkan dalam kegiatan pembelajaran sesuai dengan karakteristik aktivitas belajar siswa.

Tingkat aktivitas belajar yang terinternalisasi dalam diri diri seorang siswa akan memberikan dukungan terhadap kegiatan belajar yang dilakukannya. Aktivitas belajar belajar sebagai satu kekuatan pada diri individu dalam melakukan sesuatu tanpa tergantung orang lain tentunya mempunyai makna yang berarti bagi seorang siswa dalam merencanakan, mengelola dan menyelesaikan kegiatan belajarnya. Dapat diprediksikan bahwa apabila tingkat aktivitas belajar seorang siswa tinggi, maka dapar diharapkan siswa tersebut akan dapat mencapai hasil yang lebih baik dari rekannya.

Aktivitas belajar belajar seorang siswa mempunyai makna bagi upaya peningkatan kemampuan dalam belajar sekaligus dalam kerangka mencapai hasil belajar yang diperolehnya. Siswa dengan tingkat aktivitas belajar tinggi ditandai dengan kecenderungan: (1) tidak bergantung pada orang lain, (2) berinisiatif, (3) motivasi belajar tinggi dan (4) tidak mudah 
menyerah, sedangkan siswa dengan tingkat aktivitas belajar rendah ditandai dengan kecenderungan: (1) selalu bergantung pada orang lain, (2) kurang inisiatif, (3) motivasi belajar rendah, (4) cepat menyerah.

Rerata hasil belajar Al-Qur'an Hadits siswa Madrasah Tsanawiyah Negeri 3 Simalungun yang diajar dengan strategi pembelajaran kooperatif STAD dan aktivitas belajar tinggi $(\bar{X}=32)$ lebih tinggi daripada hasil belajar Al-Qur'an Hadits siswa Madrasah Tsanawiyah Negeri 3 Simalungun dengan aktivitas belajar rendah $(\bar{X}=25)$. Sedangkan pada strategi pembelajaran ekspositori, rata-rata hasil belajar Al-Qur'an Hadits siswa Madrasah Tsanawiyah Negeri 3 Simalungun dengan aktivitas belajar tinggi $(\bar{X}=28)$ lebih tinggi daripada hasil belajar Al-Qur'an Hadits siswa Madrasah Tsanawiyah Negeri 3 Simalungun dengan aktivitas belajar rendah $(\bar{X}=26,14)$.

Hal ini menunjukkan bahwa faktor karakteristik aktivitas belajar signifikan untuk membedakan hasil belajar Al-Qur'an Hadits siswa Madrasah Tsanawiyah Negeri 3 Simalungun, di mana hasil belajar AlQur'an Hadits siswa dengan aktivitas belajar tinggi, baik yang diajar dengan strategi pembelajaran kooperatif STAD maupun strategi pembelajaran ekspositori lebih tinggi daripada hasil belajar Al-Qur'an Hadits siswa dengan aktivitas belajar rendah. Secara khusus bagi siswa dengan aktivitas belajar rendah dalam kegiatan pembelajaran Al-Qur'an Hadits diberikan tugas-tugas yang lebih banyak sehingga dapat menutupi kelemahan terhadap penguasaan materi Al-Qur'an Hadits.

Pengujian hipotesis kedua menunjukkan bahwa hasil belajar AlQur'an Hadits siswa Madrasah Tsanawiyah Negeri 3 Simalungun dengan aktivitas belajar tinggi lebih tinggi dari pada hasil belajar Al-Qur'an Hadits siswa dengan aktivitas belajar rendah. Temuan ini membuktikan bahwa aktivitas belajar signifikan untuk membedakan hasil belajar AlQur'an Hadits. Selanjutnya hasil analisis data secara keseluruhan diperoleh rerata hasil belajar Al-Qur'an Hadits siswa dengan aktivitas belajar tinggi lebih tinggi daripada hasil belajar Al-Qur'an Hadits siswa dengan aktivitas belajar rendah.

Hal ini berindikasi bahwa siswa yang dengan aktivitas belajar tinggi mempunyai hasil belajar Al-Qur'an Hadits yang lebih tinggi dibandingkan dengan siswa dengan aktivitas belajar rendah. Dengan demikian siswa dengan aktivitas belajar tinggi dapat lebih memahami dan menguasai materi pelajaran Al-Qur'an Hadits dibandingkan siswa dengan aktivitas belajar rendah.

Pengujian hipotesis ketiga menunjukkan terdapat interaksi antara strategi pembelajaran dan aktivitas belajar dalam mempengaruhi hasil belajar Al-Qur'an Hadits siswa Madrasah Tsanawiyah Negeri 3 Simalungun. Apabila dilihat rata-rata hasil belajar Al-Qur'an Hadits pada kelompok siswa dengan aktivitas belajar tinggi dan diajar dengan strategi pembelajaran kooperatif STAD lebih tinggi dibandingkan dengan rata- 
rata hasil belajar Al-Qur'an Hadits kelompok siswa dengan aktivitas belajar rendah dan diajar dengan strategi pembelajaran ekspositori.

Rata-rata hasil belajar Al-Qur'an Hadits pada kelompok siswa Madrasah Tsanawiyah Negeri 3 Simalungun dengan aktivitas belajar rendah dan diajar dengan strategi pembelajaran kooperatif STAD lebih rendah dibandingkan dengan rata-rata hasil belajar Al-Qur'an Hadits kelompok siswa dengan aktivitas belajar rendah dan diajar dengan strategi pembelajaran ekspositori.

Hal ini bermakna bahwa bagi kelompok siswa Madrasah Tsanawiyah Negeri 3 Simalungun dengan aktivitas belajar rendah lebih baik diajar dengan menggunakan strategi pembelajaran ekspositori dibandingkan dengan menggunakan strategi pembelajaran kooperatif STAD. Dengan demikian dapatlah ditarik kesimpulan bahwa strategi pembelajaran dan aktivitas belajar signifikan mempengaruhi hasil belajar Al-Qur'an Hadits siswa. Berdasarkan hasil ini maka guru dalam pelaksanaan pembelajaran yang dilaksanakan guru harus memperhatikan karakteristik siswa dalam hal ini karakteristik aktivitas belajar. Pemilihan strategi pembelajaran atau kemampuan mendesain pembelajaran AlQur'an Hadits yang tepat dibutuhkan dan harus disesuaikan dengan karakteristik siswa sehingga akan membantu dalam menentukan strategi pembelajaran, teori belajar, dan media belajar yang cocok untuk digunakan. Hal ini dilakukan agar pelajaran yang disampaikan dapat menarik perhatian siswa dan setiap jam pelajaran tidak terasa membosankan.

Memperhatikan cakupan keluasan dan kedalam materi ajar AlQur'an Hadits, maka dibutuhkan suatu strategi pembelajaran yang mampu untuk mendeskripsikan secara rinci, mendefenisikan dan memahami konsep-konsep, memahami teori-teori dan mampu mengevaluasi dan melakukan ketrampilan dalam pembelajaran yang efektif dan efesien. Dengan demikian siswa tersebut diharapkan mampu untuk membangun atau mengkonstruk sendiri pengetahuan dan ketrampilan yang dibutuhkan untuk memecahkan masalah-masalah belajarnya. Di samping itu siswa harus menemukan sendiri pengetahuan dan ketrampilan tesebut, dan bukan karena diberitahukan oleh orang lain.

Selain itu diharapkan siswa mampu untuk menentukan sendiri materi-materi penting untuk kebutuhan belajarnya. Siswa mampu belajar secara aktif dan mandiri dengan mengembangkan atau menggunakan gagasan-gagasan dalam menyelesaikan masalah pembelajaran, sehingga pengetahuan dan ketrampilan akan dapat diingat dan dipahami dalam memori jangka panjang, dan sewaktu-waktu dapat digunakan sesuai dengan kebutuhan belajar siswa.

Berdasarkan hasil penelitian ini dapat dikatakan bahwa strategi pembelajaran disesuaikan dengan karakteristik siswa yakni aktivitas belajar dan materi pelajaran yang disampaikan. Jika guru memperhatikan karakteristik siswa, maka besar kemungkinan guru dapat memilih strategi 
pembelajaran yang tepat, sehingga siswa akan memperoleh hasil belajar Al-Qur' an Hadits yang lebih maksimal.

Hal ini sejalan dengan ungkapan Gagne dan Briggs (2008) menjelaskan ada dua fakror atau kondisi yang mempengaruhi terjadinya peristiwa belajar yaitu faktor internal dan faktor eksternal. Faktor internal adalah: (1) pengetahuan faktual, yaitu apa yang telah diketahui seseorang, (2) kemampuan intelektual, kemampuan ini harus sesuatu yang telah dipelajari agar kecakapan itu dapat dimunculkan pada waktunya, (3) strategi belajar, seseorang memiliki berbagai strategi ketika berada dalam suatu situasi belajar yang berbeda. Keadaan internal ini merupakan prakondisi untuk keberhasilan pembelajaran.

\section{SIMPULAN}

Simpulan yang dapat ditarik dari hasil penelitian adalah sebagai berikut: (1) terdapat pengaruh yang signifikan penerapan strategi pembelajaran kooperatif STAD terhadap hasil belajar Al-Qur'an Hadits. Hal ini dapat dilihat dari rata-rata hasil belajar Al-Qur'an Hadits siswa yang diajar dengan strategi pembelajaran kooperatif STAD lebih tinggi dibandingkan dengan rata-rata hasil belajar Al-Qur'an Hadits siswa yang diajar dengan strategi pembelajaran ekspositori. Dengan demikian strategi pembelajaran kooperatif STAD lebih efektif diterapkan dalam pembelajaran Al-Qur'an Hadits guna meningkatkan hasil belajar AlQur'an Hadits siswa tanpa memperhatikan adanya perbedaan aktivitas belajar, (2) terdapat pengaruh yang signifikan aktivitas belajar terhadap hasil belajar Al-Qur'an Hadits. Hal ini dapat dilihat dari rata-rata hasil belajar Al-Qur'an Hadits siswa dengan aktivitas belajar tinggi yang diajar dengan strategi pembelajaran kooperatif STAD maupun strategi pembelajaran ekspositori lebih tinggi dibandingkan dengan rata-rata hasil belajar Al-Qur'an Hadits siswa dengan aktivitas belajar rendah, dan (3) terdapat interaksi antara strategi pembelajaran dan aktivitas belajar siswa yang memberikan perbedaan pengaruh terhadap hasil belajar Al-Qur'an Hadits.

\section{REKOMENDASI}

Rekomendasi yang dapat disampaikan: (1) kepada Kepala Madrasah kiranya dapat memfasilitasi iklim belajar di madrasah yang memungkinkan bagi guru untuk memberikan ruang dan kesempatan yang seluas-luasnya bagi siswa untuk dapat melakukan aktivitas belajar sesuai dengan tuntutan kurikulum, (2) kepada guru agar melaksanakan pembelajaran dengan memberikan ruang kebebasan yang cukup bagi siswa untuk untuk terlibat dalam proses belajarnya dan membangun pengetahuannya sendiri sesuai dengan apa yang dialaminya, dan (3) kepada Peneliti lain, untuk mengkaji hal-hal yang belum terungkap dalam penelitian ini berkenaan dengan hasil belajar siswa yakni dengan 
menambah faktor-faktor lebih banyak lagi selain dari variabel aktivitas belajar.

\section{DAFTAR PUSTAKA}

Agung, Iskandar. (2010) Meningkatkan Kreativitas Pembelajaran Bagi Guru. Jakarta: Bestari Buana Murni.

Al-Tabany, Trianto Ibnu Badar. (2014) Mendesain Model Pembelajaran Inovatif, Progesif, Dan Kontekstula. Jakarta: Prenada Media Group.

Dimyati dan Moedjiono. (2009) Belajar dan Pembelajaran, Jakarta: Rineka Cipta.

Djamarah, Syaiful Bahri dkk, (2002). Strategi Belajar Mengajar. Jakarta: Rineka Cipta, .

Gulo, W. (2008) Strategi Belajar Mengajar. Jakarta: Grasindo.

Haidir dan Salim, (2012) Strategi Pembelajaran Suatu Pendekatan Bagaimana Meningkatkan Kegiatan Belajar Siswa Secara Transformatif. Medan: Perdana Publishing.

Hamalik, Oemar. Proses Belajar Mengajar. Jakarta: Bumi Aksara, 2003.

Isjoni, (2007) Pembelajaran Visioner Perpaduan Indonesia-Malaysia. Yoyyakarta: Pustaka Pelajar.

Nasution, S. Dikdaktik Asas-Asas Mengajar. Jakarta: Bumi Aksara, 2005.

Prawiradilaga. (2008) Dewi. S. Prinsip Desain Pembelajaran. Jakarta: Universitas Negeri Jakarta

Rusmono, ((2012) Strategi Pembelajaran Dengan Problem Based Learning Itu Perlu Untuk Meningkatkan Porfesionalitas Guru. Bogor: Ghalia Indonesia.

Sagala, Syaiful. (2012) Konsep dan Makna Pembelajaran. Bandung: Alfabeta.

Sanjaya, Wina. (2014) Strategi Pembelajaran, Berorientasi Standar Proses Pendidikan. Jakarta: Prenada Media Group.

Slameto. (2003) Belajar dan Faktor-Faktor yang Mempengaruhinya. Jakarta: Rineka cipta

Slavin, Robert E. (2005) Cooperative Learning, Teori, Riset dan Praktek. Bandung: Nusamedia.

Soetomo. (2003) Dasar-Dasar Interaksi Belajar Mengajar. Surabaya. Usaha Nasional.

Uno, Hamzah B. (2008) Model Pembelajaran Menciptalan Proses Belajar Mengajar Yang Kreatif dan Efektif. Jakarta: Bumi Aksara. 